\title{
Changing nature of Pleistocene interglacials - is it recorded by paleosoils in Hungary (Central Europe)?
}

\author{
GYöRGY VARGA ${ }^{1}$
}

\begin{abstract}
Based on stable isotope analyses of worldwide reference curves, it has long been apparent that duration, intensity and climatic conditions of Pleistocene interglacial periods were significantly diverse. As a consequence of negligible fresh, detrital material admixture during interglacials, the soil formation intensity and maturity of various kinds of past soils have been holding vital information on the environmental conditions at the time the soils formed. This, in turn, means that several physicochemical properties of soils allow us to reconstruct past climatic regimes. Loess-paleosol sequences in Hungary (Central Europe) provide insight into the cyclic nature of glacial-interglacial variations of the last 1 million years. The paleosoils have been recognized as the product of warmer and moister interglacials, when the (glacial) loess material was altered by chemical weathering and pedogenic processes. The gradual change from oldest red Mediterranean soils via forest and forest-steppe soils to steppe soils represents well the continuous decrease of chemical alteration of interglacial paleosoils determined by environmental factors and duration of soil formation. Pedogene units from MIS-21 to MIS-5 strata were analysed in the course of this study. Major element analyses were carried out to get a proper picture on the paleoenvironmental conditions. Geochemical transfer functions have been applied to derive mean annual precipitation and mean annual temperature. These kinds of quantitative data on past climate and the stratigraphic data allow us to fit our pedostratigraphic units into a global context. The present paper is aimed at providing new information on the various climatic and environmental characteristics of Pleistocene interglacial periods and soil forming processes.
\end{abstract}

Keywords: Pleistocene, interglacial, paleosoils, Hungary

\section{Introduction}

Recognition of past climatic changes plays a crucial role in deeper understanding of natural variability of Earth system processes. This is especially true nowadays when we would like to know more about the nature and dynamics of present climate change and about the anthropogenic influence on these variations.

Pleistocene glacial-interglacial variability represents two major opposite states of longterm climatic regimes with short transitional periods. Based on stable isotope analyses of worldwide reference curves from deep sea, ice core and speleothem records, it has long been apparent that duration, intensity and climatic conditions of different interglacial periods were significantly diverse. By the identification of driving forces leading to warm-humid periods and reconstruction of paleoenvironmental conditions of these interglacials could provide analogues to Holocene interglacial period and natural climate change dynamics.

Alternating loess and paleosoil strata of aeolian dust deposits in the Carpathian Basin are regarded as one of the most important terrestrial archives of climatic changes of the last 1 million years in Europe (MARKović, S.B. et al. 2011, 2015; ÚJvÁrI, G. et al. 2014). During cold-dry glacial periods characterised by

\footnotetext{
${ }^{1}$ Geographical Institute, Research Centre for Astronomy and Earth Sciences, Hungarian Academy of Sciences, Budaörsi út 45, H-1112 Budapest, Hungary E-mail: varga.gyorgy@csfk.mta.hu
} 
high dust fluxes, the deposited mineral dust particles accumulated in large quantities and formed into loess deposits. Warm and moist interstadials and interglacials favoured to weathering processes and soil formation. As a consequence of negligible fresh, detrital material admixture during these intervals, the soil formation intensity and maturity of various kinds of past soils have been holding vital information on the environmental conditions that prevailed at the time of their formation. This, in turn, means that several physical and chemical properties of soils allow us to reconstruct past climatic regimes.

The detailed differentiation and climatic characterisation of past soil forming periods is limited by various kinds of problems, discussed in detail e.g. by CATT, J.A. (1988). The precise dating of soil forming periods; the detachment of climatic factors from those related to parent material or relief; the mathematical relations between soil features and climate and several other questions make these estimations difficult and tough. In case of buried paleosoils in well-dated loess sequences, however, most of these difficulties can be arranged. Paleo-geomorphological conditions of soil formation and geochemical properties of parent material are very similar in case of some long loess-paleosoil series, while the duration of pedogenesis can be obtained from the proper age-depth model of the sequence. Mathematical relations between climatic factors and geochemical composition of soils have been widely investigated, and the emergence of new paleoclimate transfer functions from geochemical data provide the opportunity to quantify environmental conditions of soil formation; and so, to distinguish various kinds of warm-moist phases of the Pleistocene period (SHELDON, N.D. and ТАвоR, N.J. 2009). Weathering indices, major element ratios and paleoclimate transfer functions provide information on past environments (Kovács, J. et al. 2011, 2013). According to Schatz, A.-K. et al. (2015), glacial loess samples allow also us to quantify environmental conditions that prevailed at the time of their formation, because loess deposits can be regarded as moderately pedogenised (loessified) aeolian dust deposits (PÉCsI, M. 1990; Smalley, I. et al. 2011).

As in the course of previous studies, mainly the glacial wind-blown loess deposits have been extensively investigated, the aim of this paper is to provide new information on the various climatic and environmental characteristics of Pleistocene interglacial periods and soil forming processes.

\section{Materials and methods}

\section{Time-frame}

Pleistocene main climatic fluctuations have been controlled by the forcing of 100, 41 and 19-23 ka orbital cycles (Hays, J.D. et al. 1976). The superimposition of several harmonic cycles with different wavelength and amplitude creates non-harmonic cycles, clearly visible on reconstructed summer insolation curves. The dominant orbital driver of the various long-term climatic regimes was different from time to time. In the Pliocene, the 19-23 kyr precessional cycles were the dominant, at about the onset of the Northern Hemisphere glaciation $(\sim 2.6-2.8 \mathrm{Ma})$ the obliquityrelated $41 \mathrm{kyr}$ cycles can be identified as the main factor, and until about $1 \mathrm{Ma}$ the $100 \mathrm{kyr}$ cycles became the prominent (RAYMO, M.E. et al. 1997; DeMenocal, P.B. 2004; Lisiecki, L.E. and RAYмo, M.E. 2005, 2007). The physical mechanisms driving to the change from a 41 kyr to a 100 kyr world, the so-called "Middle Pleistocene Revolution" (similarly to the Early/Middle Pleistocene transition from 19--23 kyr to 41 kyr cycles) are not well understood. However, the typical, 100 kyr glacial-interglacial variations of the last 1 million years cannot be characterised by homogeneous and equivalent cold and warm fluctuations. Differences in the duration of interglacials have long been apparent in paleoclimate records of the Late and Middle Pleistocene.

The LR04 curve from 57 globally distributed benthic $\delta^{18} \mathrm{O}$ records have been used as primary reference curve (LISIECKI, L.E. and 
RAyмo, M.E. 2005). Odd and even marine isotope stage boundaries have been distinguished based on this database. The proxies of climatic changes of the last 800 thousand years were also archived in ice cores. The EPICA DOME C (EDC) $\delta D$ record has been applied to get another independent archive of Middle and Late Pleistocene environmental variations (EPICA Community Members 2004). The climatic fluctuations of the last glacial-interglacial period can be observed more properly from the archives of Greenland ice cores. The synthetic Greenland ( $\left.\mathrm{GL}_{T-} \mathrm{syn}\right)$ record, constructed from the EDC $\delta \mathrm{D}$ record, based on the bipolar-seesaw model was the third investigated reference curve to get a proper global time frame on the global climatic changes (BARKER, S. et al. 2011).

The three reference curves unevenly spaced in time (intervals between sampling times are different and not constant) were rescaled to equal with millennial time intervals. The amplitude of the curves was also fairly different because of the different applied paleotemperature proxies (benthic $\delta^{18} \mathrm{O}$ vs. ice $\delta \mathrm{D})$. Standardized values of amplitudinal scores were used to define warm (sub-)stages (interglacials and interstadials). Warm periods were determined as periods with above average mean temperature. The interglacial (interstadial) intensities were calculated from the multiplied values of duration and standardized mean values between the onset and the end of an identified warm period.

\section{Geological setting and samples}

Samples from Hungarian key-sites were collected (Dunaföldvár, Dunaszekcső, Paks, Tamási). Loess deposits in Central Europe provide insight into the cyclic nature of the last 1 million years. The intercalated paleosoils have been recognized as the product of warmer and moister periods, when the loess material was altered by chemical weathering and pedogenic processes. Wind-blown loess and loess-like deposits are widely distributed in the Carpathian Basin, covering more than half of the area. The Upper and partly, the Middle Pleistocene loess deposits are intercalated by steppe, forest-steppe and brown forest soils, while the older pedogene horizons are different kinds; these are red, Mediterranean-type soils. Traditionally, based on its lithology, five main units have been distinguished; the Dunaújváros-Tápiósüly series and the Mende-Basaharc series belong to the young loess sediments, the Paks I. and Paks II. series belong to the old loess sediments, while the oldest strata of the sequence is part of the Dunaföldvár series. This last section consists of thin loess horizons between red (Mediterranean-type) paleosols, reddish clays and loess-like deposits, underlain by aeolian red clay.

\section{Geochemical transfer function}

Soil properties are products of several different factors: climate, time, parent material, relief and organisms (JENNY, H. 1941). Degree of chemical weathering is dependent on climatic conditions, on parent material and on post depositional addition of fresh mineral dust to the weathering profile. The geochemical characteristics of Hungarian loess deposits are fairly homogeneous (ÚJVÁRI, G. et al. 2008) and the interglacial dust addition could have played only a minor role in the interglacial soil formation in the case of most Hungarian paleosoils. In the case of paleosoil samples from the well-dated and documented Paks loess-paleosoil series, parent material and relief conditions can be regarded similar along the whole sequence.

Thus, climate-related paleoweathering conditions have been reflected in the major elemental geochemical composition of paleosoil samples, and geochemical transfer functions can be applied to derive mean annual precipitation (MAP) and mean annual temperature (MAT) estimates. The quantitative assessment of climatic indicators relies on the selective removal of soluble and mobile elements from the soils compared to the relative enrichment of non-soluble elements. The 
relationship between the XRF-based data and the climatic parameters has been obtained from precipitation, temperature and majorelement data of modern soils from North America. Major element data were used as input of the paleoenvironment indicator geochemical transfer functions to quantify mean annual precipitation and temperature (for further details of the method see SHELDON, N.D. et al. 2002; and NorTD, L.C. and Driese, S.G. 2010 and the references therein).

The following functions were applied:

- MAP-1 = -259.3 Ln $\left(\sum\right.$ bases $\left./ A 1\right)+759$ (SHELdon, N.D. et al. 2002),

- MAP-2 = -130.9 Ln(Ca/Al) + 467 (Sheldon, N.D. et al. 2002),

- MAP-3 = 221. 1e0.0179 $\times($ CIA-K $)$, where CIA-K = $\mathrm{Al} /(\mathrm{Al}+\mathrm{Na}+\mathrm{Ca}) \times 100($ Sheldon, N.D. et al . 2002),

- MAT-1 = $46.9(\mathrm{Al} / \mathrm{Si})+4($ Sheldon, N.D. 2006),

- MAT-2 = -18.5 $(\mathrm{K}+\mathrm{Na}) / \mathrm{Al}+17.3$ (SHELDON, N.D. et al. 2002),

- MAT-3 = -2.74 Ln(PWI +21.39 , where $\mathrm{PWI}=(4.2 \mathrm{Na}+1.66 \mathrm{Mg}+5.54 \mathrm{~K}+2.05 \mathrm{Ca}) \times$ 100 (Gallagher, T.M. and Sheldon, N.D. 2013).

\section{Results and discussion}

\section{The global time frame}

Based on the calculations, we could estimate the exact duration of warm, soil forming periods and define warm, average and cold interglacials. According to the findings, the MIS-5e (duration: 18-20 kyr), MIS-9e (duration: 16-18 kyr), MIS-11c (duration: 26-34 kyr) and MIS-15c (duration: 14-20 kyr, but not so intense) periods provided the most suitable paleoenvironmental conditions for intense soil formation in a global context, from a theoretical viewpoint. Analyses of loess-paleosoil sequences of Hungary have shown a fairly good agreement with these assumptions, but some uncertainties still exist, and most of these obscurities are connected to the older stratigraphic units (Figure 1, Table 1).

\section{(Paleo)climate of the studied area}

Present day climate of the region is determined by three competing climatic regimes: (1) Atlantic; (2) continental and (3) Mediterranean. The mean annual temperature is $\sim 10.5$ ${ }^{\circ} \mathrm{C}$, while the mean annual precipitation is between 600 and $700 \mathrm{~mm}$. To get a proper picture on past climate conditions, paleoclimate transfer functions were used, while the stratigraphic position of the paleosoils were determined based on previously published studies (PÉCsI, M. and Schweitzer, F. 1995; GÁbris, G. 2007, ÚJvÁRI, G. et al. 2014).

The MIS-5 pedocomplex (MF2 unit) consist of three parts at several Hungarian sites, however the pedogene units cannot be correlated unequivocally with the three MIS-5 warmer substages, due to the scarce absolute age data. The MIS-7 (BD1 and BD2) and MIS-9 (BA) stages are represented by three forest steppe soils. The MIS-11 pedocomplex (MB) and the lowermost rubefied soils MIS19 (PD1), MIS-21 (PD2) and MIS-23 (PDK) units are thick and well-developed forest soils, formed under a more humid climate compared to the younger pedogene strata. The chronological subdivision of old paleosoils is based on the controversial position of Matuyama-Brunhes Boundary (MIS-19), the only reference point, which was placed at the last time in the uppermost part of the PD2 soil (SARTORI, M. et al. 1999). However, MIS-17 was a relatively cold interglacial as it was recorded by global reference curves. From a pedostratigraphic point of view, the discussed soils are well-developed, rubefied forest soils representing a warmer phase, a more intense interglacial period. The calculations resulted a mean annual temperature of $10.6-10.7^{\circ} \mathrm{C}$ for these soils, while the precipitation values were ranged from 830 to 850 $\mathrm{mm} /$ year, suggesting that the PD1 soil cannot be formed during the cold MIS-17 stage. According to the studies of BASARIN, B. et al. (2014) and Buggle, B. et al. (2014) MIS-17 is represented the by V-S6 fossil Cambisol and its iron mineralogical proxies indicate lower temperature and/or more summer precipi- 


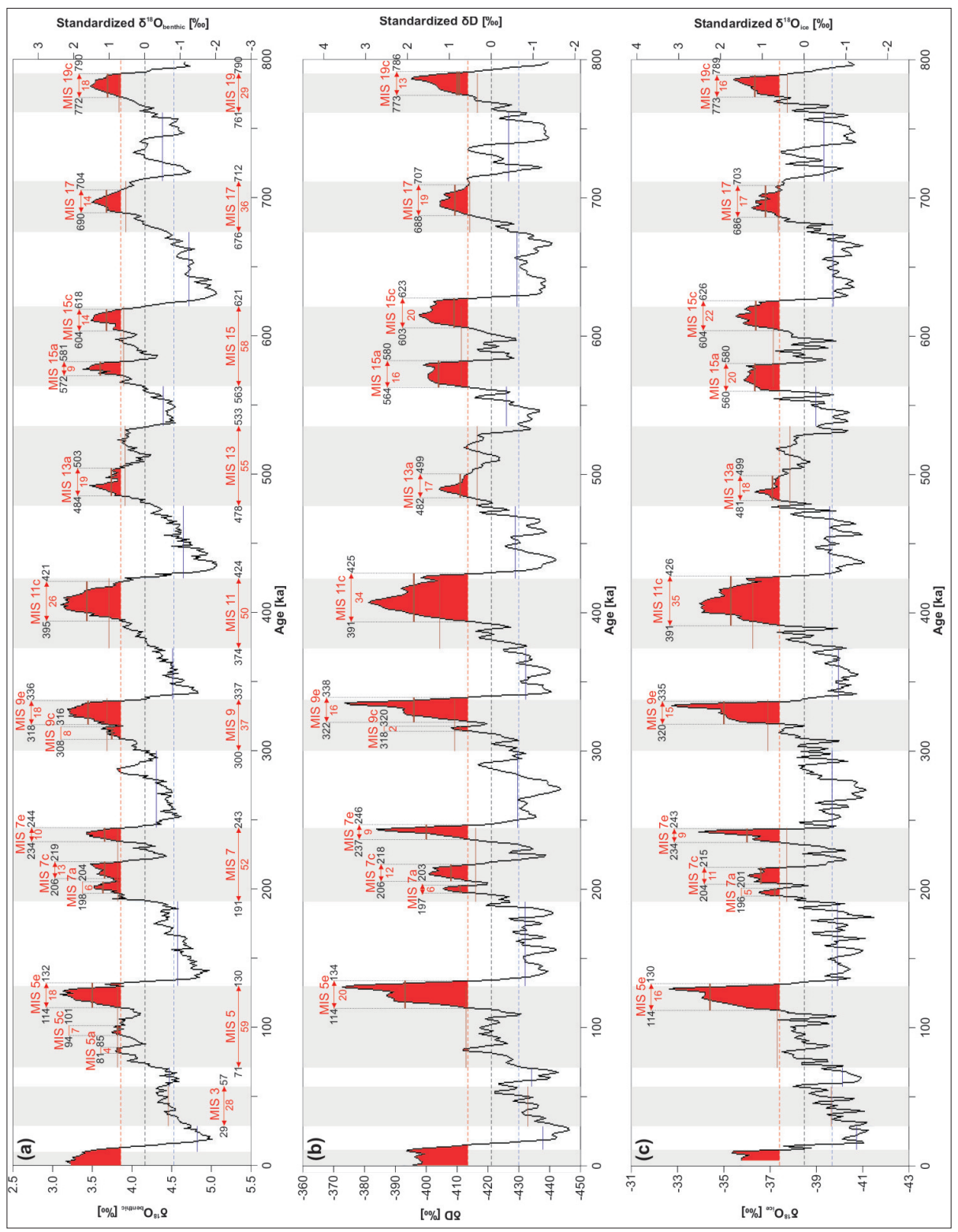

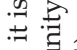

范

के हैं

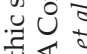

艺部

8 .

항 떼

$\approx \bar{y}$

$\ddot{\mathrm{i}} \frac{\mathrm{o}}{\mathrm{\sigma}}$

㑒

일

ฮี ซั 3

$\Xi$.

U 흔

च

$\Rightarrow$

过

$\Xi 0$

8 牙

艺

过。

需

ช 용

ฮำ

焉立国

¿

on

产

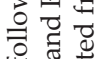

둘

平实

岁氞

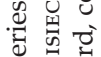

क

त

ค

客㐘

8 음

范

范荎

Е.

पे

के है है

造:

. का

政元

牙

.

정

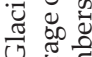

ज. है

긴

这 
Table 1. Quantified intensities and differences of Middle and Late Pleistocene interglacials based on global reference curves*

\begin{tabular}{|c|c|c|c|c|c|c|}
\hline \multicolumn{7}{|c|}{ LR04 benthic $\delta^{18} \mathrm{O}$ stack } \\
\hline Age & End & Start & Duration & Mean & St_mean & Intensity \\
\hline MIS 5a & 81 & 85 & 4 & 3.84 & 0.70 & 2.80 \\
\hline MIS 5c & 94 & 101 & 7 & 3.83 & 0.74 & 5.20 \\
\hline MIS 5e & 114 & 132 & 18 & 3.50 & 1.48 & 26.59 \\
\hline MIS 7a & 198 & 204 & 6 & 3.64 & 1.16 & 6.95 \\
\hline MIS 7c & 206 & 219 & 13 & 3.65 & 1.13 & 14.73 \\
\hline MIS 7e & 234 & 244 & 10 & 3.65 & 1.14 & 11.39 \\
\hline MIS 9c & 308 & 316 & 8 & 3.75 & 0.91 & 7.24 \\
\hline MIS 9e & 318 & 336 & 18 & 3.45 & 1.57 & 28.27 \\
\hline MIS 11c & 395 & 421 & 26 & 3.41 & 1.66 & 43.26 \\
\hline MIS 13a & 484 & 503 & 19 & 3.73 & 0.95 & 18.08 \\
\hline MIS 15a & 572 & 581 & 9 & 3.61 & 1.23 & 11.08 \\
\hline MIS 15c & 604 & 618 & 14 & 3.67 & 1.08 & 15.16 \\
\hline MIS 17 & 690 & 704 & 14 & 3.67 & 1.09 & 15.20 \\
\hline MIS 19c & 772 & 790 & 18 & 3.69 & 1.04 & 18.63 \\
\hline & & Mean & 13.14 & 3.65 & 1.13 & 16.04 \\
\hline & & St. dev. $(\sigma)$ & 6.19 & 0.13 & 0.28 & 10.79 \\
\hline & & $-1 \sigma$ & 6.96 & 3.52 & 0.85 & 5.25 \\
\hline & & $+1 \sigma$ & 19.33 & 3.78 & 1.42 & 26.84 \\
\hline & & $-1 / 2 \sigma$ & 10.05 & 3.59 & 0.99 & 10.65 \\
\hline & & $+1 / 2 \sigma$ & 16.24 & 3.71 & 1.28 & 21.44 \\
\hline \multicolumn{7}{|c|}{ EPICA DOME C ice core record [ठD] } \\
\hline MIS 5a & - & - & - & - & - & - \\
\hline MIS 5c & - & - & - & - & - & - \\
\hline MIS 5e & 114 & 134 & 20 & -393.13 & 2.08 & 41.53 \\
\hline MIS 7a & 197 & 203 & 6 & -410.88 & 0.76 & 4.54 \\
\hline MIS 7c & 206 & 218 & 12 & -407.86 & 0.98 & 11.78 \\
\hline MIS 7e & 237 & 246 & 9 & -400.19 & 1.55 & 13.96 \\
\hline MIS 9c & 318 & 320 & 2 & -410.04 & 0.82 & 1.64 \\
\hline MIS 9e & 322 & 338 & 16 & -396.04 & 1.86 & 29.76 \\
\hline MIS 11c & 391 & 425 & 34 & -396.23 & 1.85 & 62.75 \\
\hline MIS 13a & 482 & 499 & 17 & -411.16 & 0.74 & 12.52 \\
\hline MIS 15a & 564 & 580 & 16 & -404.78 & 1.21 & 19.37 \\
\hline MIS 15c & 603 & 623 & 20 & -409.30 & 0.87 & 17.49 \\
\hline MIS 17 & 688 & 707 & 19 & -409.34 & 0.87 & 16.56 \\
\hline MIS 19c & 773 & 786 & 13 & -410.20 & 0.81 & 10.50 \\
\hline & & Mean & 15.33 & -404.93 & 1.20 & 20.20 \\
\hline & & St. dev. $(\sigma)$ & 8.15 & 6.69 & 0.50 & 17.14 \\
\hline & & $-1 \sigma$ & 7.18 & -411.62 & 0.70 & 3.06 \\
\hline & & $+1 \sigma$ & 23.48 & -398.24 & 1.70 & 37.34 \\
\hline & & $-1 / 2 \sigma$ & 11.26 & -408.27 & 0.95 & 11.63 \\
\hline & & $+1 / 2 \sigma$ & 19.41 & -401.59 & 1.45 & 28.77 \\
\hline
\end{tabular}


Table 1. (continued)

\begin{tabular}{|c|c|c|c|c|c|c|}
\hline \multicolumn{7}{|c|}{ GLT_syn: synthetic Greenland $\delta^{18} \mathrm{O}$ record } \\
\hline Age & End & Start & Duration & Mean & St_mean & Intensity \\
\hline MIS 5a & - & - & 0 & - & - & - \\
\hline MIS 5c & - & - & 0 & - & - & - \\
\hline MIS 5e & 114 & 130 & 16 & -34.53 & 2.15 & 34.35 \\
\hline MIS 7a & 196 & 201 & 5 & -37.28 & 0.65 & 3.25 \\
\hline MIS 7c & 204 & 215 & 11 & -36.62 & 1.01 & 11.12 \\
\hline MIS 7e & 234 & 243 & 9 & -35.99 & 1.35 & 12.16 \\
\hline MIS 9c & - & - & 0 & - & - & - \\
\hline MIS 9e & 320 & 335 & 15 & -35.04 & 1.87 & 28.07 \\
\hline MIS 11c & 391 & 426 & 35 & -35.27 & 1.75 & 61.08 \\
\hline MIS 13a & 481 & 499 & 18 & -37.08 & 0.76 & 13.60 \\
\hline MIS 15a & 560 & 580 & 20 & -36.35 & 1.16 & 23.16 \\
\hline MIS 15c & 604 & 626 & 22 & -36.37 & 1.15 & 25.21 \\
\hline MIS 17 & 686 & 703 & 17 & -36.77 & 0.93 & 15.76 \\
\hline MIS 19c & 773 & 789 & 16 & -36.37 & 1.15 & 18.35 \\
\hline & & Mean & 16.73 & -36.15 & 1.26 & 22.37 \\
\hline & & St. dev. $(\sigma)$ & 7.80 & 0.87 & 0.47 & 15.54 \\
\hline & & $-1 \sigma$ & 8.93 & -37.02 & 0.79 & 6.83 \\
\hline & & $+1 \sigma$ & 24.53 & -35.28 & 1.74 & 37.92 \\
\hline & & $-1 / 2 \sigma$ & 12.83 & -36.59 & 1.03 & 14.60 \\
\hline & & $+1 / 2 \sigma$ & 20.63 & -35.72 & 1.50 & 30.15 \\
\hline
\end{tabular}

*Colours indicate the deviation by \pm 0.5 and $1 \sigma$ from the mean values; abbreviations: st_mean: standardized mean; st. dev: standard deviation).

tation, an unsuitable condition for rubefied brown forest soil formation.

Contrary to the global loess-paleosoil sequences, the MIS-13 and MIS-15 soils are not so dominant in the Hungarian series. The two brown forest soils and two pseudogley soils could be located only in the Paks loess section, but their geochemical data suggest an intense weathering history. According to the calculations, the older paleosoils were formed under a warmer and moister climate compared to the younger pedogene units. The reconstructed paleoprecipitation and paleotemperature values are showing a general trend of weathering intensity decrease (Figure 2).

\section{Conclusions}

Geochemical proxies demonstrate a general decreasing chemical weathering trend over the last 800 kyr in the Carpathian Basin. This decreasing trend could be caused by (1) less humid and mild interglacials and/or by (2) enhanced erosion of the dust source areas which has resulted an enhanced input of relatively unweathered material. It is worth noting that, the applied proxies are not capable to distinguish pre- and post-depositional weathering. The younger soils were formed completely from the underlying loess deposits of the preceding glacial periods, and there was no interglacial dust deposition or it could be neglected, while according to previous granulometric studies (e.g. VARGA, GY. 2011), the different grain size characteristics of the older soils reflect a largely different depositional system. Interglacial dust deposition played a more dominant role during the formation of the red paleosoils; similarly to certain types of red clays.

The possibility of significant interglacial aeolian dust deposition is leading to several other questions. According to the classical 


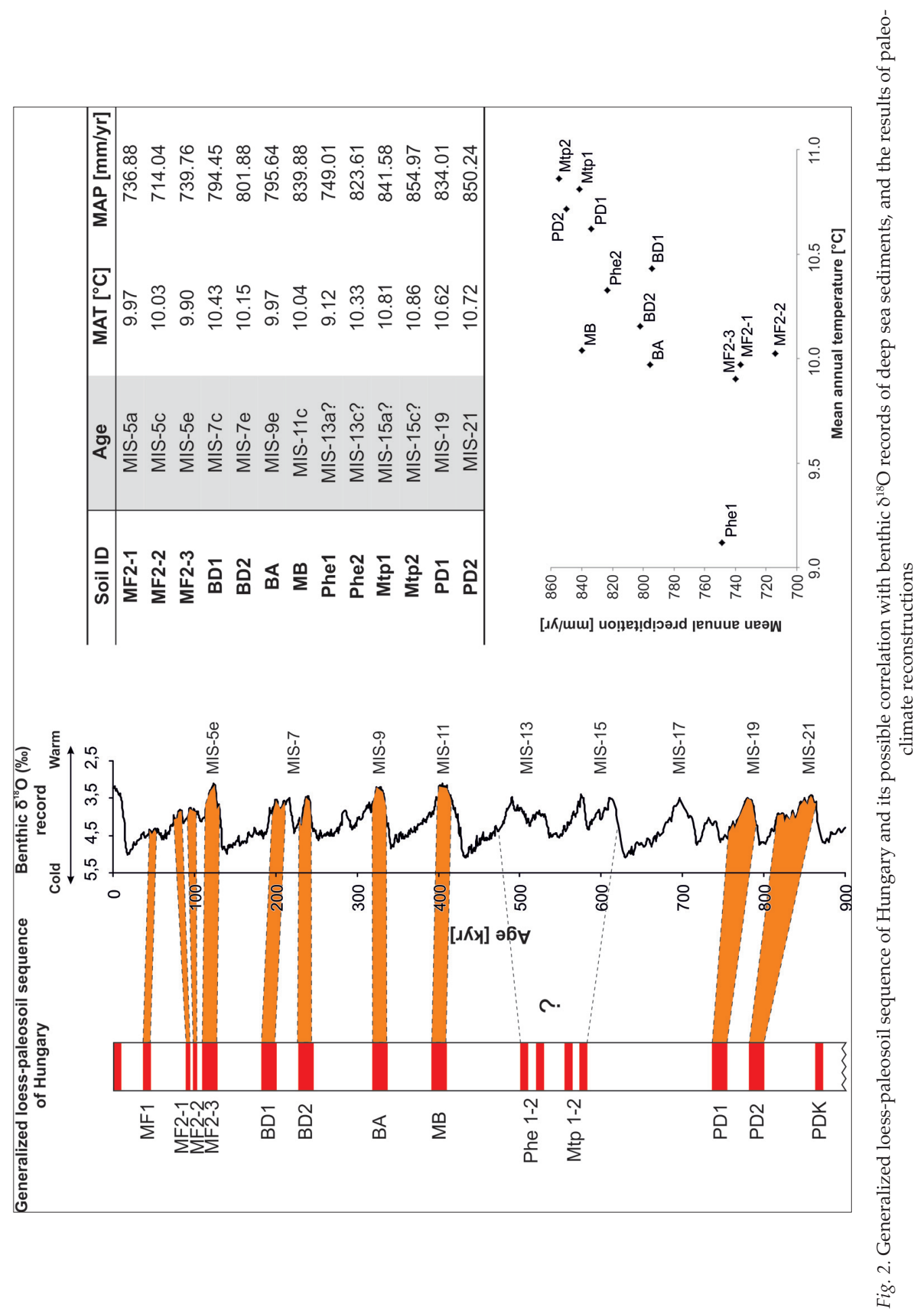


assumption, the loess deposits have been formed from the depositing dust material, while the paleosoils developed from the underlying loess deposits by weak weathering processes. However, intensive interglacial dust accumulation claims a different kind of stratigraphic interpretation. In the first case, when the soils were formed from the underlying deposits, the last period of loess formation could not have been identified as loess layer in the sequence. In the second case, the soils form syngenetically from the falling dust, and all of the changes are represented in the stratigraphic column. From a paleoclimatic viewpoint, these glacial-interglacial shifts and abrupt warmings of glacial climax periods are one of the most interesting research topics.

The paleoprecipitation and paleotemperature data of the widely used geochemical climofunctions deserve also further reconsideration. The fine-grained populations of deposits are consisting of detrital and secondary particles; only the secondary ones provide relevant information on the environmental properties of the soil formation. By the assessment of the amount of detrital, windblown clay-minerals the result of these reconstructions could be refined significantly.

Acknowledgement: Support of the Hungarian Research Fund OTKA under contract PD108708 is gratefully acknowledged. It was additionally supported by the Bolyai János Research Scholarship of the Hungarian Academy of Sciences.

\section{REFERENCES}

Barker, S., Knorr, G., Edwards, R.L., Parrenin, F., Putnam, A., Skinner, L.C., Wolff, E. and Ziegler, M. 2011. 800,000 years of abrupt climate variability. Science 21. 347-351.

Basarin, B., Buggle, B., Hambach, U., Marković, S.B., O'Hara Dhand, K., Kovačević, A., Stevens, T., Guo, Z. and Lukić, T. 2014. Time-scale and astronomical forcing of Serbian loess-paleosol sequences. Global and Planetary Change 122. 89-106.

Buggle, B., Hambach, U., Müller, K., Zöller, L., Marković, S.B. and Glaser, B. 2014. Iron mineralogical proxies and Quaternary climate change in SE-European loess-paleosol sequences. Catena 117. 4-22.
Catt, J.A. 1988. Soils of the Plio-Pleistocene: do they distinguish types of interglacial? Philosophical Transactions of the Royal Society of London. Series B 318. 539-557.

DEMenocal, P.B. 2004. African climate change and faunal evolution during the Pliocene-Pleistocene. Earth and Planetary Science Letters (Frontiers) 220. 3-24.

EPICACommunity Members 2004. Eight glacial cycles from an Antarctic ice core. Nature 429. 623-628.

GÁbRIs, G. 2007. The relation between the time scale of the Quaternary surface processes and oxygen isotope stratigraphy - according to the loess-palaeosoil sequences and river terraces in Hungary. Földtani Közlöny 137. 515-540.

Gallagher, T.M. and Sheldon, N.D. 2013. A new paleothermometer for forest paleosols and its implications for Cenozoic climate. Geology 41. 647-650.

Hays, J.D., Imbrie, J. and Shackleton, N.J. 1976. Variations in the earth's orbit: pacemaker of the ice ages. Science 194. 1121-1132.

Jenny, H. 1941. Factors of Soil Formation - A System of Quantitative Pedology. New York, Dover Publications, 281 p.

Kovács, J., FÁbIÁN, S.T., VARgA, G., ÚJváRI, G., VARGA, G. and Dezsô, J. 2011. Plio-Pleistocene red clay deposits in the Pannonian basin: A review. Quaternary International 240. 35-43.

Kovács, J., Raucsik, B., VArga, A., ÚJváRI, G., VARgA, G. and Ottner, F. 2013. Clay mineralogy of red clay deposits from the Central Carpathian Basin (Hungary): Implications for Plio/Pleistocene chemical weathering and paleoclimate. Turkish Journal of Earth Sciences 22. 414-426.

Lisiecki, L.E. and RAYMo, M.E. 2005. A Plio-Pleistocene stack of 57 globally distributed benthic $\mathrm{d}^{18} \mathrm{O}$ records. Paleoceanography 20. PA1003

LisiecKI, L.E. and RAYMo, M.E. 2007. Plio-Pleistocene climate evolution: trends in obliquity and precession responses. Quaternary Science Reviews 26. 56-69.

Marković, S.B., Hambach, U., Stevens, T., Kukla, G.J., Heller, F., McCoy, W.D., Oches, E.A., Buggle, B. and ZöLLER, L. 2011. The last million years recorded at the Stari Slankamen (Northern Serbia) loesspalaeosol sequence: revised chronostratigraphy and long-term environmental trends. Quaternary Science Reviews 30. 1142-1154.

Marković, S.B., Stevens, T., Kukla, G.J., Нambach, U., Fitzsimmons, K.E., Gibbard, P., Buggle, B., Zech, M., Guo, Z., Hao, Q., Wu, H., O'Hara Dhand, K., Smalley, I.J., ÚJváRI, G., SÜMegi, P., Timar-Gabor, A., Veres, D., Sirocko, F., Vasiljević, D.A., Jary, Z., Svensson, A., Jović, V., Lehmkuhl, F., Kovács, J. and SvirčEv, Z. 2015. Danube loess stratigraphy - Towards a pan-European loess stratigraphic model. Earth-Science Reviews 148. 228-258.

Nordt, L.C. and Driese, S.G. 2010. A modern soil characterization approach to reconstructing 
physical and chemical properties of paleo-vertisols. American Journal of Science 310. 37-64.

PÉcsi, M. 1990. Loess is not just the accumulation of dust. Quaternary International 7-8. 1-21.

Pécsi, M. and Schweitzer, F. 1995. The lithostratigraphical, chronostratigraphical sequence of Hungarian loess profiles and their geomorphological position. In Concept of loess, loess-paleosol stratigraphy. Loess InForm 3. Eds.: Pécsi, M. and Schweitzer, F. Budapest, Geographical Research Institute HAS, 31-61.

Raymo, M.E., Oppo, D.W. and Curry, W. 1997. The mid-Pleistocene climate transition: a deep sea carbon isotope perspective. Paleoceanography 12 . 546-559.

Sartori, M., Heller, F., Forster, T., Borkovec, M., Hammann, J. and Vincent, E. 1999. Magnetic properties of loess grain size fractions from the section at Paks (Hungary). Physics of the Earth and Planetary Interiors 116. 53-64.

Schatz, A.-K., Scholten, T. and Kühn, P. 2015. Paleoclimate and weathering of the Tokaj (Hungary) loess-paleosol sequence. Palaeogeography, Palaeoclimatology, Palaeoecology 426. 170-182.

SHELDON, N.D. 2006. Quaternary glacial-interglacial climate cycles in Hawaii. Journal of Geology 114. 367-376.
Sheldon, N.D. and TABor, N.J. 2009. Quantitative paleoenvironmental and paleoclimatic reconstruction using paleosols. Earth-Science Reviews 95. 1-52.

Sheldon, N.D., Retallack, G.J. and Tanaka, S. 2002. Geochemical climofunctions from North American soils and application to paleosols across the EoceneOligocene boundary in Oregon. Journal of Geology 110. 687-696.

Smalley, I., Marković, S.B. and Svirčev, Z. 2011. Loess is (almost totally formed by) the accumulation of dust. Quaternary International 24. 4-11.

Újvári, G., VARGA, A. and BAlogh-Brunstad, Z. 2008. Origin, weathering, and geochemical composition of loess in southwestern Hungary. Quaternary Research 69. 421-437.

Újvári, G., VArga, A., Raucsik, B. and Kovács, J. 2014. The Paks loess-paleosol sequence: A record of chemical weathering and provenance for the last $800 \mathrm{ka}$ in the mid-Carpathian Basin. Quaternary International 319. 22-37.

VARGA, G. 2011. Similarities among the Plio-Pleistocene terrestrial aeolian dust deposits in the world and in Hungary. Quaternary International 234. 98-108. 